\title{
Linked sucrose synthase genes in group-7 chromosomes in hexaploid wheat (Triticum aestivum L.)
}

(Recombinant DNA; endosperm cDNA clones; genetic mapping; wheat-maize linkage conservation; gene evolution; wheat aneuploids; non-stringent hybridization; probe)

\section{Carmen Maraña, Francisco García-Olmedo and Pilar Carbonero}

Departamento de Bioquímica, Escuela Técnica Superior de Ingenieros Agrónomos, Madrid (Spain)

\section{SUMMARY}

A cDNA library from developing wheat endosperm was screened for sucrose-synthase clones using a maize cDNA probe corresponding to the $S h l$ locus under non-stringent conditions. Five positive clones were isolated and initially classified into two types on the basis of their relative ability to hybridize with the probe and of their partial restriction maps. Determination of the nucleotide sequences indicated homology between the two types of wheat clones, with type 1 showing higher homology to the maize Shl locus than to type-2 sequences. The inserts cloned in plasmids pST8 (type 1) and pST3 (type 2) were used as probes to determine the chromosomal locations of the two types of genes. DNAs from compensated nulli-tetrasomic and ditelosomic lines of wheat cultivar Chinese Spring were cleaved with EcoRI and analysed in Southern blots. DNA segments of the two types were thus identified in the short arms of chromosomes 7A, 7D, and, possibly, 7B. The two types of linked loci have been designated $S s I$ and $S s 2$, respectively.

\section{INTRODUCTION}

The enzyme sucrose synthase (EC 2.4.1.13) catalyzes the reversible cleavage of sucrose into

Correspondence to: Dr. P. Carbonero, Departamento de Bioquímica, Escuela Técnica Superior de Ingenieros Agrónomos, Ciudad Universitaria, 28040 Madrid (Spain) Tel. (1) 2444807.

Abbreviations: AMV, avian myeloblastosis virus; bp, base pair(s); BSA, bovine serum albumin; cv., cultivar; dap, days after pollination; kb, kilobase(s) or $1000 \mathrm{bp}$; nt, nucleotide(s); PI, P2 probes, see RESULTS AND DISCUSSION, section a; PolIk, Klenow (large) fragment of $E$. coll DNA polymerase I; SDS, sodium dodecyl sulfate; SSPE, see MATERIALS AND METHODS, section e.
UDP-glucose and D-fructose. Two genes encoding sucrose synthase ( $S h l$ and $S s 2$ or $C s s$ ) have been described in maize (Chourey and Nelson, 1976; Chourey, 1981a, 1986; McCormick et al., 1982) and the corresponding isozymes were shown to have partial antigenic identity and very similar kinetic properties in the sucrose-cleavage reaction (Echt and Chourey, 1985). Shl is the structural gene for the major endosperm form of the enzyme which is a homotetramer composed of subunits of $92 \mathrm{kDa}(\mathrm{Su}$ and Preiss, 1978; Chourey, 1981b; Werr et al., 1985). This gene is expressed in other tissues at low levels that can be drastically increased in response to anaerobiosis (Springer et al., 1986). The second gene, $S s 2$ or $C s s$, is also expressed in several tissues 
but its expression is less affected by anaerobiosis (McCarty et al,, 1986a). The $S h 1$ gene has been cloned and its entire DNA sequence has been determined (Geiser et al., 1980; 1982; Sheldon et al., 1983; Werr et al., 1985; Zack et al., 1986). Based on the ability of $S h l$ probes to select by hybridization mRNA corresponding to the Css gene (McCormick et al., 1982), Css genomic clones have been isolated and characterized by McCarty et al. (1986a) who have also located the Css (Ss2) gene near the centromere of chromosome 9 of maize, 32 map units from the $S h l$ locus (McCarty et al., 1986b). We report here the existence of linked non-allelic sucrose synthase genes in wheat chromosomes of homoeologous group 7 .

\section{MATERIALS AND METHODS}

\section{(a) Biological material}

Hexaploid wheat Triticum aestivum L. cv. Chinese Spring and its aneuploids (compensated nulli-tetrasomics and ditelosomics) were the gift of Dr. E.R. Sears (Columbia, MO). A cDNA clone (pKS500) corresponding to the maize $S h l$ sucrose synthase was provided by Dr. P. Starlinger (Köln, F.R.G.).

\section{(b) Reagents}

Chemicals used were of analytical grade. Restriction enzymes, T4-DNA ligase, PolIk and other enzymes were obtained from Boehringer, Amersham, New England Biolabs, or Pharmacia. $\left[\alpha^{-32} \mathrm{P}\right] \mathrm{dATP}$ or $\left[\gamma_{-}{ }^{32} \mathrm{P}\right] \mathrm{ATP}$ were from Amersham.

\section{(c) Construction and screening of a cDNA library}

The construction and screening of a wheat cDNA library was carried out by standard procedures (Maniatis et al., 1982). Total polysomal RNA from developing endosperm (20 dap) of wheat ( $T$. aestivum L. cv. Chinese Spring) was the source of the poly(A) ${ }^{+}$RNA used as the template for the AMV-reverse transcriptase reaction. After secondstrand synthesis with Pollk and size fractionation by $1.5 \%$ agarose gel electrophoresis the DNA of more than 500 bp was purified (Dretzen et al., 1981) and ligated into the SmaI site of plasmid $\mathrm{pUCl} 2$ and used to transform competent cells of Escherichia coli JM83 (Vieira and Messing, 1982). The library was screened using as a probe the nick-translated ${ }^{32}$ P-labeled insert from pKS500 (Geiser et al., 1980).

\section{(d) Nucleotide sequence analysis}

Plasmid DNA was isolated from bacterial cultures using the alkaline lysis method of Birnboim and Doly (1979) and purified by $\mathrm{CsCl}$-gradient ultracentrifugation when required. Restriction maps of the clones were drawn by established procedures and nucleotide sequences were obtained by the chemical modification method of Maxam and Gilbert (1980). 5 '-overhang restriction sites were labeled with $\left[\gamma-{ }^{32} \mathrm{P}\right] \mathrm{ATP}$ and polynucleotide kinase, and then a second restriction cut was performed at the appropriate site of the pUC polylinker. Subcloning was carried out in the same pUC12 plasmid.

Computer-assisted analysis of nucleotide and deduced amino acid sequences was performed using the 'Micro-Genie' program from Beckman (Queen and Korn, 1984).

\section{(e) DNA blots, RNA blots and hybridization}

Genomic DNA was isolated from 7-day-old darkgrown wheat seedlings essentially as described by Murray and Thompson (1980). Restriction digestion, agarose gel electrophoresis and Southern blotting to nylon membranes (Hybond N, Amersham) were performed according to Maniatis et al. (1982) and to the manufacturer's instructions. Hybridization to nick-translated inserts of appropriate cDNA clones was in $5 \times \operatorname{SSPE}(0.9 \mathrm{M} \mathrm{NaCl}$, $0.05 \mathrm{M} \mathrm{NaH} \mathrm{PO}_{4}, \mathrm{pH} 7.4,0.005 \mathrm{M}$ EDTA), $2 \times$ Denhardt's $\quad(0.04 \% \quad$ polyvinylpyrrolidone, $0.04 \%$ BSA, $0.04 \%$ Ficoll), $0.2 \%$ SDS, $100 \mu \mathrm{g} / \mathrm{ml}$ salmon sperm DNA, at $65^{\circ} \mathrm{C}$ or at $58^{\circ} \mathrm{C}$, according to the stringency required in each case. The RNA for Northern blots was isolated from developing endosperms (20 dap) and from 7-day-old etiolated shoots. Glyoxal-denatured RNAs (Thomas, 1983) were fractionated by electrophoresis in $1.2 \%$ agarose gels, transferred to nitrocellulose filters (Hybond C, Amersham) and hybridized as previously described (Ponz et al., 1986). 

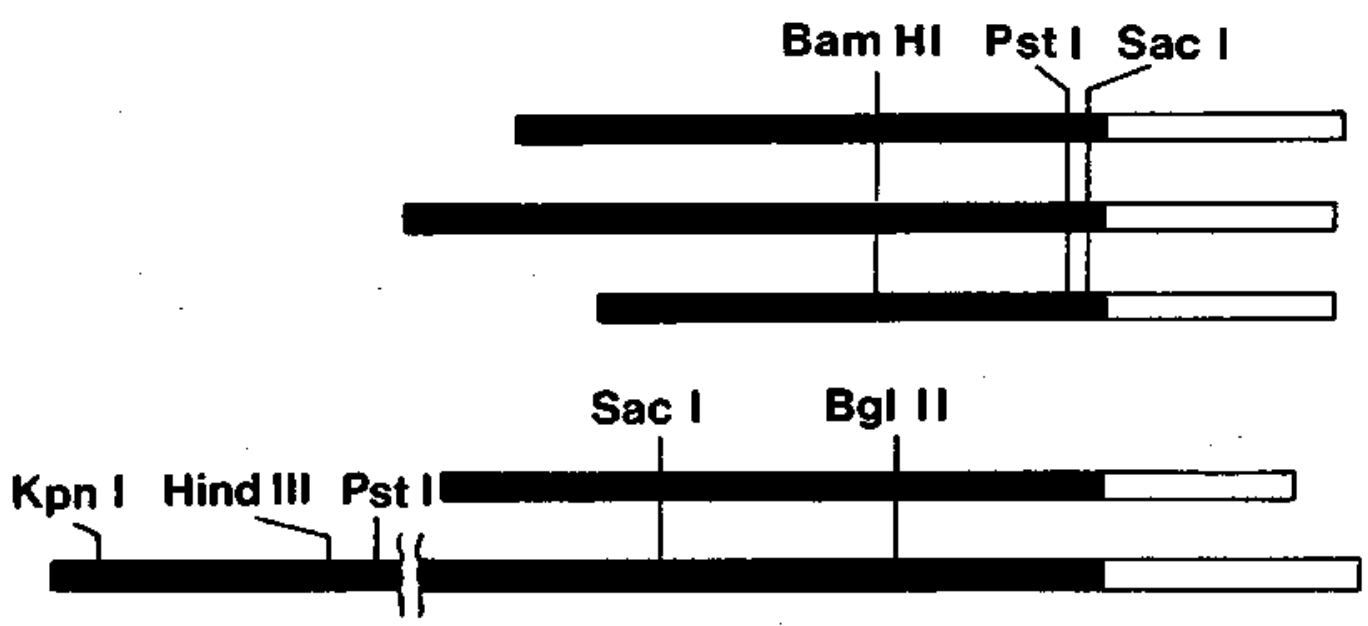

TYPE 1 pST8 ( $890 \mathrm{bp})$ pST6 ( 1005 bp) pST1 ( 790 bp) $\frac{\text { TYPE } 2}{\text { PST3 (924 bp) }}$
pST5 (1875 bp)

Fig. 1. Partial restriction maps of the inserts in cDNA clones selected from a wheat endosperm library with a maize probe corresponding to the locus $S h /$ (pKS500; Geiser et al., 1980). The library was constructed by ligation of blunt-ended cDNA into the SmaI site of plasmid pUCI 2 and transformation of competent cells of $E$. coli JM83 (see MATERIALS AND METHODS, section c). Clones were classified into two types based on their restriction maps and the relative hybridization signals (Type 1, strong; Type 2, weak). Coding regions are indicated by black bars and non-coding ones by open bars.

\section{RESULTS AND DISCUSSION}

\section{(a) Isolation and characterization of two types of sucrose synthase cDNA clones}

A cDNA library of 6000 clones, obtained from poly $(\mathrm{A})^{+}$RNA extracted from 20-dap developing wheat endosperm, was screened under non-stringent hybridization conditions with a cDNA probe (pKS500) corresponding to the Shl locus from maize. Five clones giving a positive signal were further hybridized at more stringent conditions and classified into two types, according to their apparent homology to the probe and to their partial restriction maps (Fig. 1). The nucleotide sequences of the inserts in these clones corroborated both their homology to the probe and their classification into two types. No sequence divergence was found within each type, with the exception of clone pST1, that differed from the other two of its group in less than $3 \%$ of the coding and less than $8 \%$ of the non-coding sequence positions. The 5 '-end of the largest insert, that of pST5, extended to the region corresponding to exon No. 7 of the $S h l$ gene (Werr et al., 1985; Zack et al., 1986). The inserts in clones pST8 and pST3, hereafter designated P1 and P2, were chosen as probes for subsequent gene-mapping experiments because they represented approximately equivalent

\section{TABLE I}

Comparison of coding and non-coding regions of sequences in Fig. 2.

\begin{tabular}{|c|c|c|c|c|c|c|}
\hline \multirow{4}{*}{$\begin{array}{l}\text { Wheat } \\
\text { probes }\end{array}$} & \multicolumn{6}{|c|}{$\%$ Homology $^{b}$} \\
\hline & \multicolumn{3}{|c|}{ Maize $S h I$} & \multicolumn{3}{|c|}{ Wheat P2 } \\
\hline & \multirow[t]{2}{*}{ Protein } & \multicolumn{2}{|l|}{ DNA } & \multirow[t]{2}{*}{ Protein } & \multicolumn{2}{|l|}{ DNA } \\
\hline & & Coding & Non-coding & & Coding & Non-coding \\
\hline Wheat P1 & 89.2 & 84.7 & 52.4 & 79.2 & 78.1 & 39.6 \\
\hline Wheat P2 & 77.1 & 73.8 & 46.6 & 100 & 100 & 100 \\
\hline
\end{tabular}

a The sequences between nucleotides 69 and 687 have been used as aligned in Fig. 2 to calculate the \% bomology between DNA-coding regions and between deduced amino acid sequences. Non-coding sequences have been compared using the 'Micro-Genie' program.

b The numbers indicate the $\%$ of coincident residues between the compared sequences. 
Sh1 GCGCGTCTCGACCGCGTGAAGAACATEACAGECETGGTCGAGATGTACGgCAAGAACGCGCECCTGAGGGAGCTGGCGAACCTCGTEATCGTTGCC

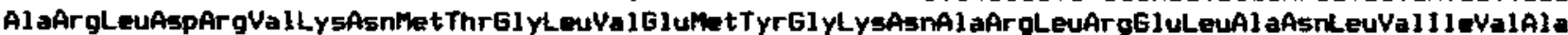

P1

P2

Sh1

P1

P2

Sh1

P1

P2

Sh1

P1

P2

P1

P2

Sh1

P1

P2

Sh1

P1

P2

Sh1

P1

P2

Sh1

P1

P2

Sh1

P1

P2

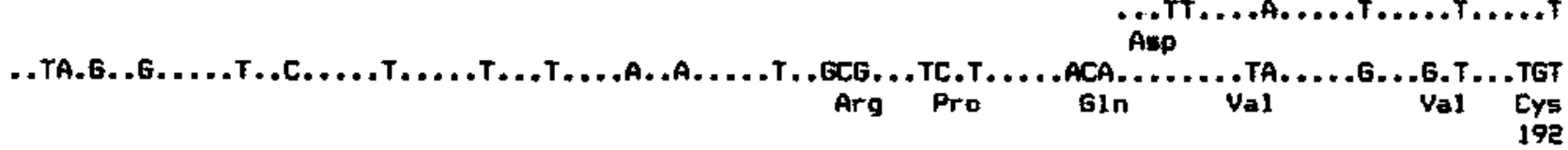

GGT6ACCACGGCAAGGAGTCCAAGGACAGGGAGGAGCAGGCGGAGTTCAAGAAGATGTACAGCCTCATCGACGAGTACAAGTTGAAGGGCCATATC

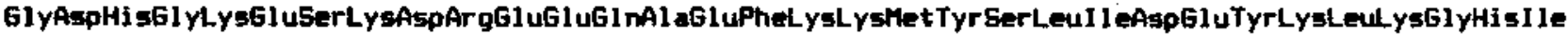

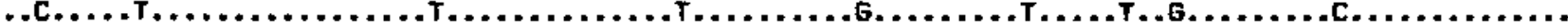
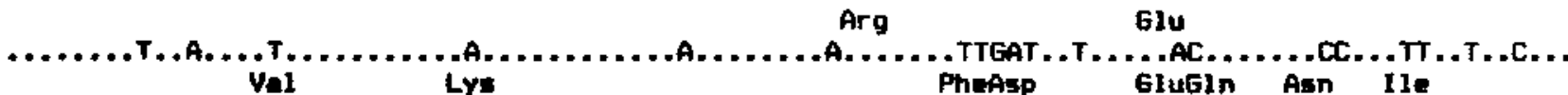

CGGTGGATCTCGGCGCAGATEAACCGTGTCCECAACGGGGAECTGTACCGCTACATTTECGATACCAAGGGCGCATTCGTECAGCCTECGTTCTAC ArgTrpI leSerAl agl nMetAsnArgValArgAsnGl yGluLeuTyrArgTyr I leCysAsp ThrLys61 yAl aPheVal6lnProAl aPheTyr

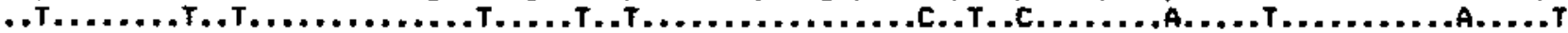

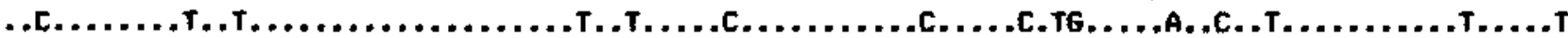
Net

GAAGCGTTCGGCCTGACTGTGATCGAGTCCATGACGTGCGGTCTGCCAACGATCGCGACCTGCCATGGCGGCCCTGCTGAGATCATCGTEGACGGG

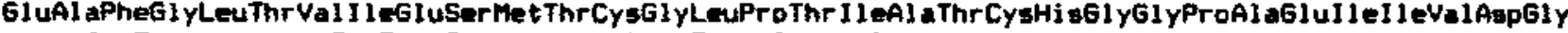

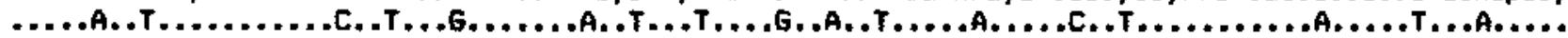
Ala Asn

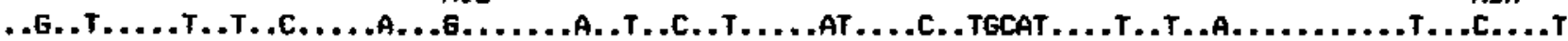
Ala Phe Alatyr Hi 5

GTATCTGGCCTGCACATTGACCCTTACCACAGCEACAAGGCCGCGGATATCCTGGTCAACTTCTTTGACAAATGCAAGGCAGATCCGAGCTACTGG ValSerGl yLeuHi I I eAspProTyrHi sSerAsplysAl aAl aAsp I leLeuVa lAsnPhePheAspLysCysLysAl aAspProSerTyrTrp

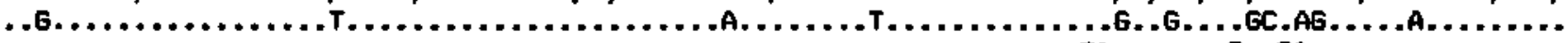

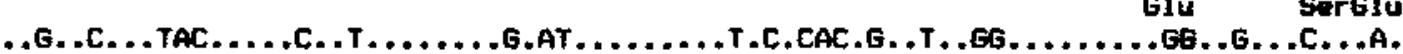
Tyr
GlnAsn
SerAlalen
Asp
Gly
Elnglu
His

GACGAGATCTCACAGGGCEECCTGCAGAGAATTTATGAGAAGTACACCTGGAAGCTCTACTCCEAGAGGCTGATGACCCTGACCEGCGTGTACGGO

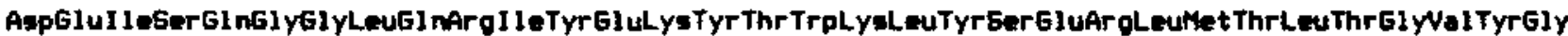

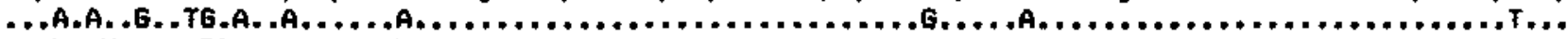
Lysthe Glu LYs

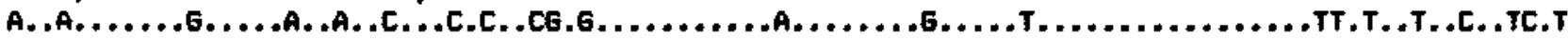
Asnlys Glu Ger Ser 672 TTCTGGAAGTACGTGASCAACCTGGAGAGGCGCGAGACCCECCGCTACATCGAGATGTTCTACGCCCTGAAGTACCGTAGCCTEGCAAGCCAGGTT PheTrpLyETyrVal SerAsnleuGluArgArgGluThrArgArgTyr I leGluMetPheTyrAl aLeuLys TyrArgSerLeuAla5erG InVal

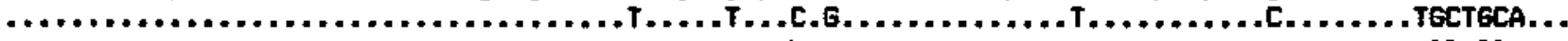
Leu AlaAla

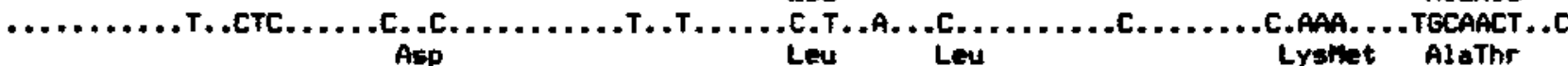

Leu

Lystivet Alathr

769

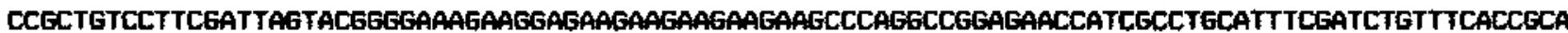
ProLeuSerPheAspEnd

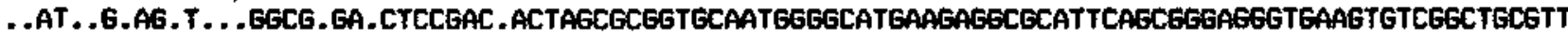
Alaval GlyGluSerSerAspAsnEnd

. .AT . .G. TG.T . . GGGCG. GACCTCGG.C.AAT . ATTTGTCCTTACCAEAGAAATAAATGGCG6GCGAGGCCTCCECTTTACCGTTCTTGATTCA Al eValGluGlyGluThrSerGlyLysEnd

ATTCECATTGTTAETCGTGTATTGGAGTTATGTGTACTTEGTTTCCAAGAACTTTGGTCCTYCTCGTTITTTTCCTTETTTEAGCGTTTTEGG ATGATITGTCTGTCTACCGTAGTTTCCATTTEGTCTEGTCGTGGGGTGTGTTAATTTGTTGTCTCGECACATTTGTGAGGTCCTAGGCAGTGCTCG GTEATGAAGCACAGATCGGAGAGTGTTATGECTTTGATTGTCCTTTGTTACCGTTETTGATTCAGTATEAACTTYAGTTCCTGTTGAGECCCCGEC

Fig. 2. Alignment of the nucleotide and amino acid sequences of wheat probes $\mathbf{P 1}$ and $\mathbf{P} 2$ with the appropriate segments of the maize $S h I$ sequences. The nucleotides have been numbered from the 5 '-end of P2. Only the variant positions have been indicated with nt or aa symbols in the coding regions, whereas identities are indicated by points. The non-coding regions are written in full and identities have not been indicated. Polyadenylation signals AATAAA are underlined and the CAYUG consensus sequences are boxed (Y - pyrimidine). The sequence of Sh1 was taken from Zack et al. (1986). The sequences of P1 and P2 reported here correspond to the inserts in plasmids pST8 and pST3, respectively (see MATERIALS AND METHODS, section d). 
regions of the $3^{\prime}$ ends of their corresponding genes. Their sequences have been aligned with the appropriate regions in the $S h l$ maize gene in Fig. 2, and binary comparisons of their coding and non-coding nucleotide sequences are presented in Table I. Divergence of the nucleotide sequences of the untranslated $3^{\prime}$ ends is considerably greater than that of the coding sequences. As expected from the hybridization experiments, P1, which yielded the strongest signal with the maize probe, shows higher \% homology with it than P2, both in the coding and in the non-coding regions. Furthermore, the sequence of $P 1$ is closer to that of maize than to that of $P 2$ in both regions, indicating an evolutionary time of divergence between the corresponding wheat genes greater than that of the wheat/maize branching out. Northern-blot analysis of total RNAs from 20-dap endosperm and from 7-day-old etiolated shoots, using $\mathrm{P} 1$ and $\mathrm{P} 2$ as probes, yielded single bands with an apparent size of about $3.1 \mathrm{~kb}$ under denaturing conditions (Fig. 3). When loading equal amounts of

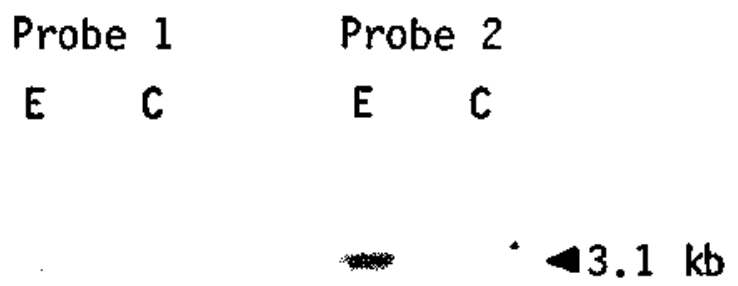

Fig. 3. Northern-blot analysis of total RNAs from endosperms (E) and coleoptiles (C), using probes P1 and P2. RNA samples (15 $\mu \mathrm{g} /$ lane) were electrophoresed in $1.2 \%$ agarose gels in $10 \mathrm{mM}$ sodium phosphate ( $\mathrm{pH}$ 7.0) after denaturation with glyoxal (Thomas, 1983), transferred to a Hybond C nitrocellulose membrane according to the manufacturer's instructions and hybridized with $10^{7} \mathrm{cpm}$ of nick-translated $\mathrm{Pl}$ or $\mathrm{P} 2$ probes per gel. The size of the RNAs in kb is shown on the right margin as estimated on the basis of the mobilities of ribosomal RNAs.

the two RNAs in electrophoresis, the signals were stronger for the endosperm than for the etjolated shoots with either probe.

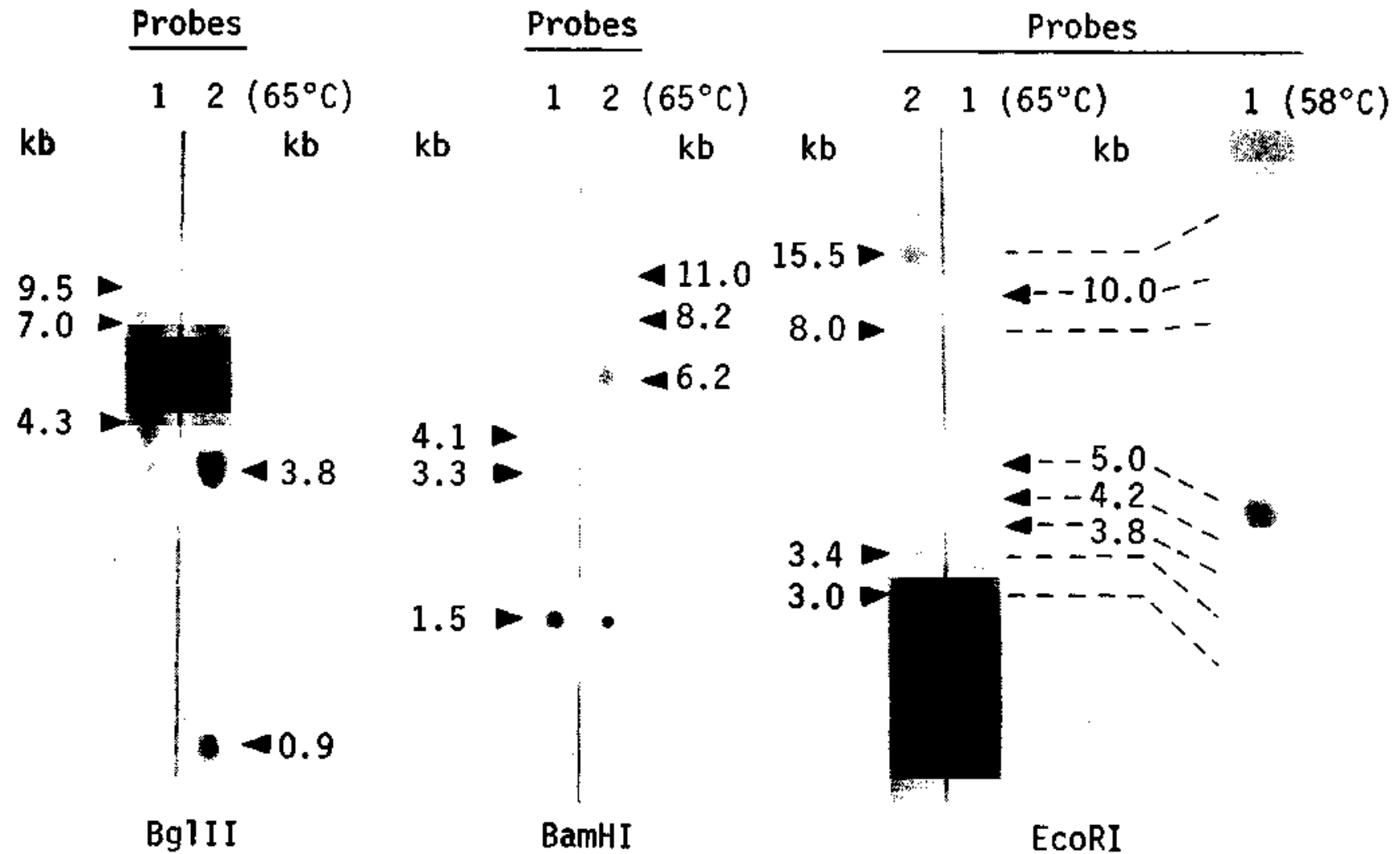

Fig. 4. Southern-blot analysis of DNA from wheat euploid cv. Chinese Spring. Genomic DNA was isolated as described by Murray and Thompson (1980). DNA samples $(30 \mu \mathrm{g})$ were digested with the indicated restriction enzymes, size-separated by electrophoresis in $0.8 \%$ agarose gels and transferred to nylon membranes (Hybond N, Amersham). These were hybridized to P1 or P2 cDNA probes (MATERIALS AND METHODS, section e). Stringent $\left(65^{\circ} \mathrm{C}\right)$ and non-stringent $\left(58^{\circ} \mathrm{C}\right)$ conditions were used as indicated. Bands that hybridize preferentially with either probe P1 or P2 are pointed out by horizontal arrowheads. The size markers run on the same gel were HindIII fragments of phage $\lambda$ DNA. 
(b) Chromosomal locations of sucrose synthase genes in wheat

Total DNA isolated from etiolated seedlings of an euploid stock of wheat cv. Chinese Spring was separately digested with restriction enzymes $B g l I I$, $B a m \mathrm{HI}$, and $E c o$ RI, fractionated by agarose gel electrophoresis, transferred to nylon membranes and hybridized with $\mathrm{P} 1$ and $\mathrm{P} 2$ under stringent conditions, as shown in Fig. 4. The different bands from each restriction pattern were preferentially labeled with one probe and gave a weaker signal or none at all with the other. Less stringent hybridization conditions allowed a more even distribution of the radioactive label (Fig. 4). The higher number of well resolved bands in the EcoRI pattern justified the choice of this enzyme to carry out the analysis of

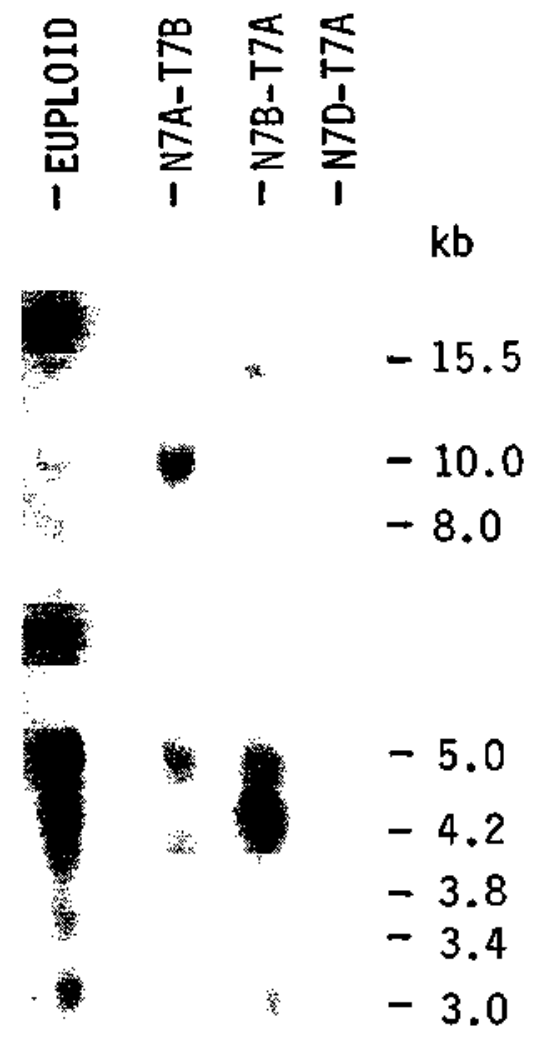

\section{Probe $1\left(58^{\circ} \mathrm{C}\right)$}

Fig. 5. Southern-blot analysis of EcoRI-digested DNAs from euploid and compensated nulli-tetrasomic lines of wheat cv. Chinese Spring, using probe P1 under non-stringent conditions $\left(58^{\circ} \mathrm{C}\right.$; see MATERIALS AND METHODS, section $e$, and Fig. 4): nulli N7A-T7B, 7A-tetra 7B; N7B-T7A, nulli 7B-tetra 7A; N7D-T7A, nulli 7D-tetra 7A.
DNAs from the different aneuploid stocks. Bands at $10.0,5.0,4.2$, and $3.8 \mathrm{~kb}$ were preferentially labeled by hybridization with $P 1$, and those at $15.5,8.0,3.4$, and $3.0 \mathrm{~kb}$ with $\mathrm{P} 2$, whereas $P 1$ at lower hybridization temperatures allowed the detection of all eight bands (Fig. 4).

The DNAs of compensated nulli-tetrasomic lines of cv. Chinese Spring, in each of which the lack of a given chromosome pair from one of the three diploid genomes of hexaploid wheat (AA, BB, DD) was compensated by two extra copies of one of its ancestral homologues (homoeologues) in the other genomes, were digested with $E c o$ RI and analysed by Southern blotting and hybridization with P1 at low stringency. Only nulli-tetrasomics of homoeologous group 7 gave patterns that differed from that of the euploid line (Fig. 5). Bands at 4.2 and $3.0 \mathrm{~kb}$ were missing in the line lacking both copies of chromosome 7A (nulli 7A-tetra 7B) and were thus assigned to this chromosome. In a similar manner, bands at $5.0,3.8$, and $3.4 \mathrm{~kb}$, which were absent in nulli 7D-tetra 7A, were assigned to chromosome 7D. The signal at $10.0 \mathrm{~kb}$ was considerably weakened in nulli 7B-tetra 7A and clearly enhanced in nulli 7A-tetra $7 \mathrm{~B}$, indicating that a DNA segment of $10.0 \mathrm{~kb}$, responsible for most of the hybridization signal, is located in chromosome 7B. The variation of band intensity at $15.5 \mathrm{~kb}$ suggests that the signal consists of about equal parts of DNA segments of that size belonging to chromosomes 7A and 7D. The band at $8.0 \mathrm{~kb}$ could not be assigned to a particular chromosome, possibly because all three homoeologous chromosomes have an equivalent DNA segment.

To confirm the above observations and to investigate in which of the chromosome arms were the sucrose synthase genes located, ditelosomics of homoeologous group 7 were analysed, using both probes, $P 1$ and $P 2$, at stringent conditions. In each of these aneuploid lines, a particular chromosome arm is missing in a given chromosome pair. Results are presented and the conclusions about chromosomal locations are summarized in Fig. 6. Ditelosomics 7AS, 7BS, and 7DS, in which only the short arms of the corresponding chromosomes were present, had the same restriction pattern as the euploid, whereas ditelosomics 7AL and 7BL which lacked the short arms of the corresponding chromosomes, reproduced the restriction patterns of the nulli-tetrasomic stocks in which the appropriate 


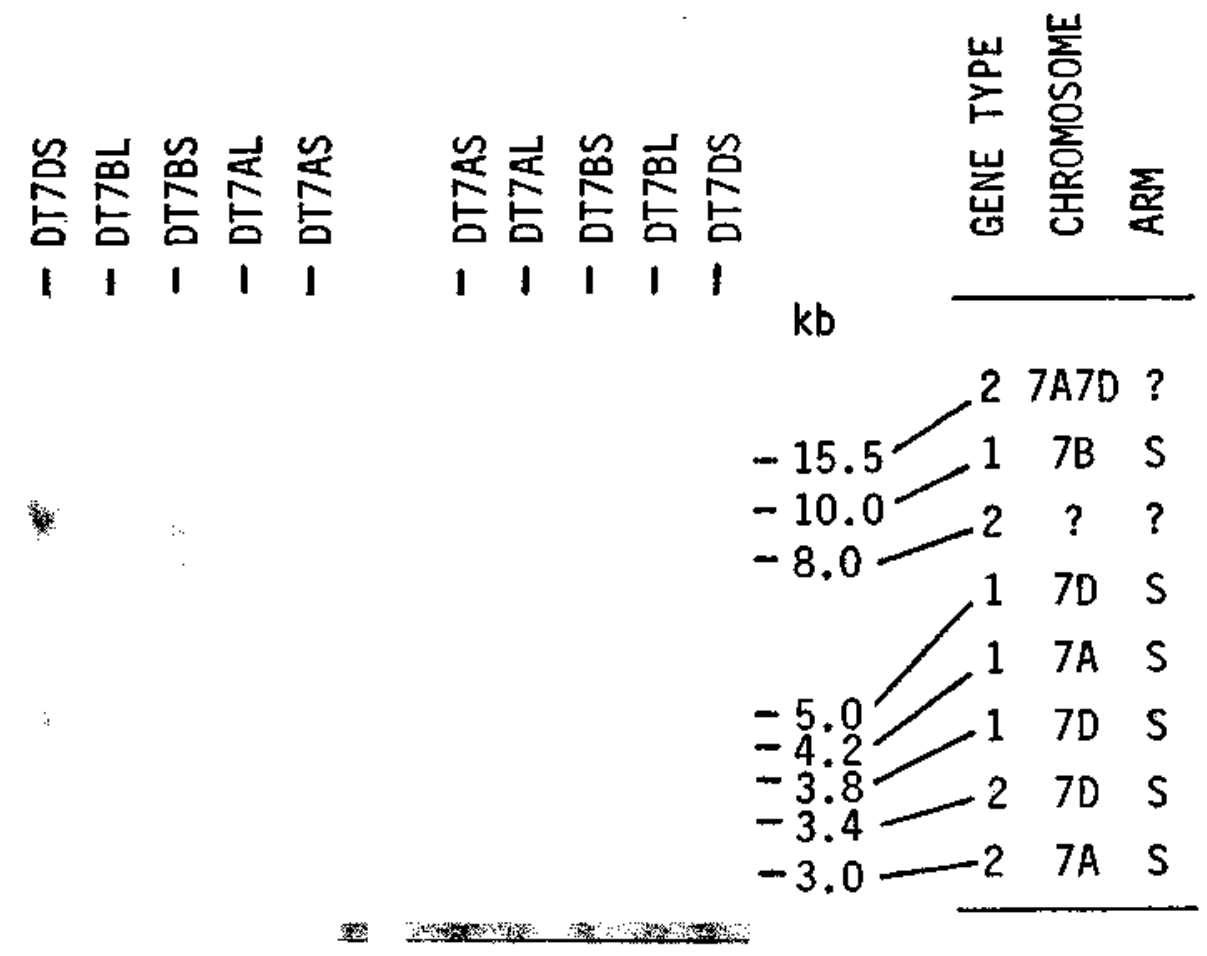

Probe $1\left(65^{\circ} \mathrm{C}\right)$ Probe $2\left(65^{\circ} \mathrm{C}\right)$

Fig. 6. Southern-blot analysis of EcoRI-digested DNAs from group-7 ditelosomic lines of wheat cv. Chinese Spring using probes P1 and P2 under stringent conditions. In ditelosomic lines DT7AS, DT7BS, and DT7DS, only the short arms of the corresponding chromosomes are present, whereas in DT7AL, and DT7BL, only the long arms are present. Assignment of bands to gene types 1 and 2 is based on data from Figs. 1, 2 and 4. Chromosome arms are designated as short (S) or long (L). Unconclusive assignment is indicated by a question mark.

whole chromosomes were absent (ditelosomic 7DL was not available). It was thus concluded that the DNA segments recognized by the probes were located in the short arms of chromosomes of homoeologous group 7. Since the DNA segments assigned to a given chromosome arm (i.e., 7AS or 7DS) are of the two types, showing preferential hybridization with either P1 (type 1) or P2 (type 2), the genes corresponding to these two probes are neither homoallelic nor homoeoallelic, but must be non-allelic and linked. Thus, the present observations allow the description of two linked loci, for which we propose the designations $S s 1$ and $S s 2$, respectively, located in the short arms of chromosomes $7 \mathrm{~A}$ and $7 \mathrm{D}$, whereas the data demonstrate an $S s 1$ locus in the short arm of chromosome 7B and are compatible with the existence of an $S s 2$, but do not prove it. In this context, the micro-heterogeneity found for the insert in clone pST1 would represent the expected variability within the $S s I$ homoeogenes. Based on the homology data deduced from the two types of probes (Table I), $S s 1$ would correspond to the $S h l$ locus of maize, while $S s 2$ of wheat could be equivalent to $S s 2$ or $C s s$ of maize. As already indicated, it has been recently reported that the $S h l$ and $S s 2$ loci are linked and associated with chromosome 9 of maize (McCarty et al., 1986b), so the present observation implies that the two loci were probably generated by intra-chromosomal duplication prior to the branching-out between wheat and maize. It will be of interest to investigate whether other wheat genes located in chromosomes of group 7 also have their maize counterparts in chromosome 9.

\section{(c) Conclusions}

(1) Two types of sucrose synthase genes have been identified in wheat, based on a comparison of the nucleotide sequences of cDNA clones isolated from developing endosperm ( 20 dap) with that of the $S h l$ gene from maize. The first type, designated $S s l$, would be equivalent to $S h l$, and the second type, 
designated $S s 2$, would correspond to the $S s 2$ or Css locus of maize.

(2) The two types of genes are present in the short arms of chromosomes 7A, 7D, and possibly 7B, as shown by Southern-blot analysis of the DNAs from compensated nulli-tetrasomic and ditelosomic lines of wheat cv. Chinese Spring.

(3) Since the two types of loci are also linked in maize, it is concluded that the two loci probably originated by intra-chromosomal duplication prior to the wheat/maize branching-out.

\section{ACKNOWLEDGEMENTS}

We would like to acknowledge the excellent technical assistance of L. Lamoneda, J. García and C. Rojas. This work was financially supported by Comisión Asesora de Investigación Científica y Técnica (grant No. 2022/83). C. Maraña is the recipient of an FPI scholarship from Ministerio de Educación y Ciencia.

\section{REFERENCES}

Birmboim, H.C. and Doly, J.: A rapid alkaline extraction procedure for screening recombinant plasmid DNA. Nucl. Acids Res. 7 (1979) 1513-1523.

Chourey, P.S.: Electrophoretic analysis of sucrose synthetase proteins in the complementing heterozygotes at the shrunken locus in maize. Theor. Appl. Genet. 59 (1981a) 231-234.

Chourey, P.S.: Genetic control of sucrose synthetase in maize endosperm. Mol. Gen. Genet. 184 (1981b) 372-376.

Chourey, P.S.: On gene symbolization for the second sucrose synthase enzyme. Maize Genetics Coop. Newslet. V (1986) 55-56.

Chourey, P.S. and Nelson, O.E.: The enzymatic deficiency conditioned by the shrunken-1 mutations in maize. Biochem. Genet. 14 (1976) 1041-1055.

Dretzen, G., Bellard, M., Sassone-Corsi, P. and Chambon, P.S.: A reliable method for the recovery of DNA fragments from agarose and acrylamide gels. Anal. Biochem. 112 (1981) $295-298$.

Echt, C.S. and Chourey, P.S.: A comparison of two sucrose synthetase isozymes from normal and shrunken-1 maize. Plant Physiol. 79 (1985) 530-536.

Geiser, M., Dorring, H.P., Wortemeyer, J., Behrens, U., Tillmann, E. and Starlinger, P.: A cDNA clone from $Z e a$ mays endosperm sucrose synthetase mRNA. Nucl. Acids Res. 8 (1980) 6175-6188.
Geiser, M., Weck, E., Döring, H.P., Werr, W., Courage-Tebbe, U., Tilmann, E. and Starlinger, P.: Genomic clones of a wild-type allele and a transposable element-induced mutant altele of the sucrose synthase gene of Zea mays L. EMBO J. l (1982) 1455-1460.

Maniatis, T., Fritsch, E.F. and Sambrook, J.: Molecular Cloning. A Laboratory Manual. Cold Spring Harbor Laboratory, Cold Spring Harbor, NY, 1982.

Maxam, A.M. and Gilbert, W.: Sequencing end-labelled DNA with base-specific chemical cleavages. Methods Enzymol. 65 (1980) 499-560.

McCarty, D.R., Shaw, J.R. and Hannah, L.C.: The cloning, genetic mapping, and expression of the constitutive sucrose synthase locus of maize. Proc. Nat]. Acad. Sci. USA 83 (1986a) 9099-9103.

McCarty, D.R., Wright, S., Helentjaris, T., Shaw, J. and Hannah, L.C.: The sucrose synthetase-2 gene is genetically linked to ShI. Maize Coop. Newslett. V (1986b) 60-61.

McCormick, S., Mauvais, J. and Fedorof,, N.: Evidence that the two sucrose synthetase genes in maize are related. Mol. Gen. Genet. 187 (1982) 494-500.

Murray, M.G. and Thompson, W.F.: Rapid isolation of high molecular weight plant DNA. Nucl. Acids Res. 8 (1980) $4321-4325$.

Ponz, F., Paz-Ares, J., Hernandez-Lucas, C., Garcia-Olmedo, F. and Carbonero, P.: Cloning and nucleotide sequence of a cDNA encoding the precursor of the barley toxin $\alpha$-hordothionin. Eur. J. Biochem. 156 (1986) 131-135.

Queen, C. and Korn, L.J.: A comprehensive sequence analysis program for the IBM personal computer. Nucl. Acids Res. 12 (1984) 581-599.

Sheldon, E., Ferl, R., Fedoroff, N. and Hannah, L.C.: Isolation and analysis of a genomic clone encoding sucrose synthetase in maize: evidence for two introns in $S h$. Mol. Gen. Genet. 190 (1983) 421-426.

Springer, B., Werr, W., Starlinger, P., Bennett, D.C., Zokolica, $M$. and Freeling, M.: The shrunken gene on chromosome 9 of $Z$ ea mays $\mathrm{L}$. is expressed in various plant tissues and encodes an anaerobic protein. Mol. Gen. Genet. 205 (1986) 461-468.

Su, J.-C. and Preiss, J.: Purification and properties of sucrose synthase from maize kernels. Plant Physiol. 61 (1978) 389-393.

Thomas, P.S.: Hybridization of denatured RNA transferred or dotted to nitrocellulose paper. Methods Enzymol. 100 (1983) 255-266.

Vieira, J. and Messing, J.: The pUC plasmids, an M13mp7derived system for insertion mutagenesis and sequencing with synthetic universal primers. Gene 19 (1982) 259-268.

Werr, W., Frommer, W.B., Maas, C. and Starlinger, P.: Structure of the sucrose synthase gene on chromosome 9 of Zea mays L. EMBO J. 4 (1985) 1373-1380.

Zack, C.D., Ferl, RJ. and Hannah, L.C.: DNA sequence of a shrunken allele of maize: evidence for visitation by insertional sequences. Maydica XXXI (1986) 5-16.

Communicated by $\mathbf{M}$. Salas. 